\title{
Lavandula angustifolia Mill. as a natural host of Cucumber mosaic virus (CMV)
}

\author{
Tadeusz Kobytko ${ }^{l}$, Piotr Dańda ${ }^{l}$ \\ Beata Hasiów ${ }^{2}$, Natasza Borodynko', Henryk Pospieszny ${ }^{2}$ \\ ${ }^{1}$ Department of Botany, University of Agriculture in Kraków, \\ 29 Listopada 54, 31-425 Kraków, Poland \\ ${ }^{2}$ Institute of Plant Protection, Department of Virology and Bacteriology, \\ Wegorka 20, 60-318 Poznań, Poland \\ email: zbotaniki@bratek.ogr.ar.krakow.pl
}

Key words: medicinal plant, viral disease, yellow mottling

\begin{abstract}
A virus was isolated from Lavandula angustifolia Mill. plants exhibiting yellow mottling and distortion of leaves. After mechanical inoculation it induced in the major part of used test plants symptoms characteristic for Cucumber mosaic virus (CMV). Its standard properties regarding the stability in crude plant sap were as follows: longevity in vitro $1-2$ days, thermal inactivation point $55-60^{\circ} \mathrm{C}$, dilution end point $\log _{10}$ minus $3-4$. The virus reacted positive with diagnostic antiserum against CMV in DAS-ELISA test. RT-PCR reaction revealed similarity between the investigated isolate and the isolate of CMV from the Netherlands belonging to subgroup II. In the light of the foregoing facts the isolated pathogen can be identified as the Cucumber mosaic virus and Lavandula angustifolia may be regarded as its natural host.
\end{abstract}




\section{INTRODUCTION}

English Lavender (Lavandula angustifolia Mill., syn. L. officinalis Chaix), a perennial plant (family Lamiaceae) cultivated on a large scale in some South European countries, is known in Poland mainly as an ornamental plant. On account of its little economic importance, in our country no studies of virus diseases of this species have been carried out so far. According to the available literature only the occurrence of the Alfalfa mosaic virus (AMV) on lavender plants has been reported (Giunchedi and de Ferrer 1972).

In the spring 2005 yellow mottling and leaf distortion (Fig. 1) were observed on some specimens of $L$. angustifolia cultivated in the medicinal and spice plants collection of the University of Agriculture in Kraków. A virus was isolated from the infected plants. In this paper the results of identification of the pathogen are reported.

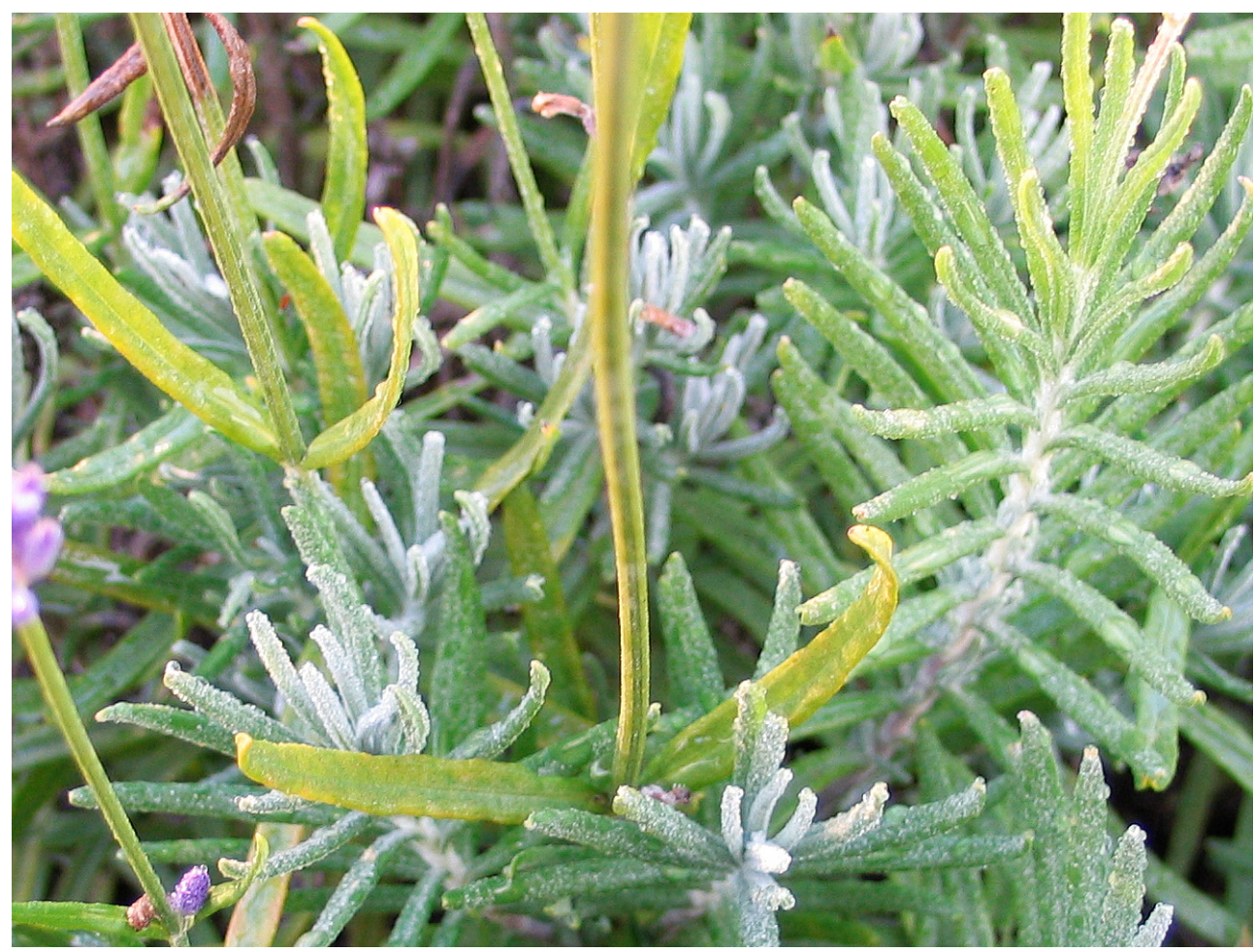

Fig. 1. Symptoms on the leaves of naturally infected Lavandula angustifolia plant 


\section{MATERIAL AND METHODS}

The virus was isolated by mechanical transmission from the diseased lavender plants to Chenopodium quinoa and Nicotiana tabacum 'Xanthi' plants.

The original material to study were young leaves of lavender exhibiting visible pathological symptoms - yellow mottling and distortion. The plants used for isolation of the pathogen were infected with the inoculum prepared from the leaves. The isolated virus was maintained and multiplied on Nicotiana tabacum 'Xanthi' plants. The sap obtained from the plants was used for inoculation of test plants, examining the virus stability and as a source of antigenes in DAS-ELISA test. The test was performed with antiserum Loewe Biochemica $\mathrm{GmbH}$ against CMV (commercial kit 07014K). The absorbances were measured at $405 \mathrm{~nm}$ using Labsystems Multiskan MS Photometer.

The identification of the pathogen was finally verified by molecular studies carried out in The Institute of Plant Protection in Poznan. Total RNA was extracted from infected Nicotiana tabacum 'Xanthi' plants by phenol-chloroform method. Reverse transcription polymerase chain reaction was carried out using specific primers designed on the basis of multiple sequences alignment of CMV sequences deposited in the GenBank database (Borodynko et al. 2004). A 367 bp PCR fragments representing a part of coat protein gene located in CMV RNA3 were cloned into pGEM-Teasy vector and sequenced two times in both directions. The obtained sequence (Accession No. EU303304) was compared with homologous sequences of CMV isolates from the GenBank database.

\section{RESULTS}

Isolation of the pathogen from the leaves of lavender proceeded without difficulties. The test plants inoculated with the isolate reacted as follows:

- Chenopodium quinoa Willd. - after 4 days chlorotic spots and subsequently their necrotisation; absence of systemic reaction.

- Cucumis sativus L. 'Monastyrski' - absence of local symptoms on the cotyledones, chlorotic spots on young leaves and subsequently mosaic symptoms (Fig. 2).

- Datura stramonium L. - after 8 days chlorotic spots and after 14 days chlorotic ringspots (Fig. 3).

- Nicotiana glutinosa L. - after 6 days chlorotic spots on inoculated leaves, after 10 days systemic reaction in form of mosaic, necrosis and leaf malformation.

- Nicotiana tabacum L. 'Xanthi' - after 6 days local chlorotic spots and necrotic rings, after 8 days mosaic on young leaves (Fig. 4). 


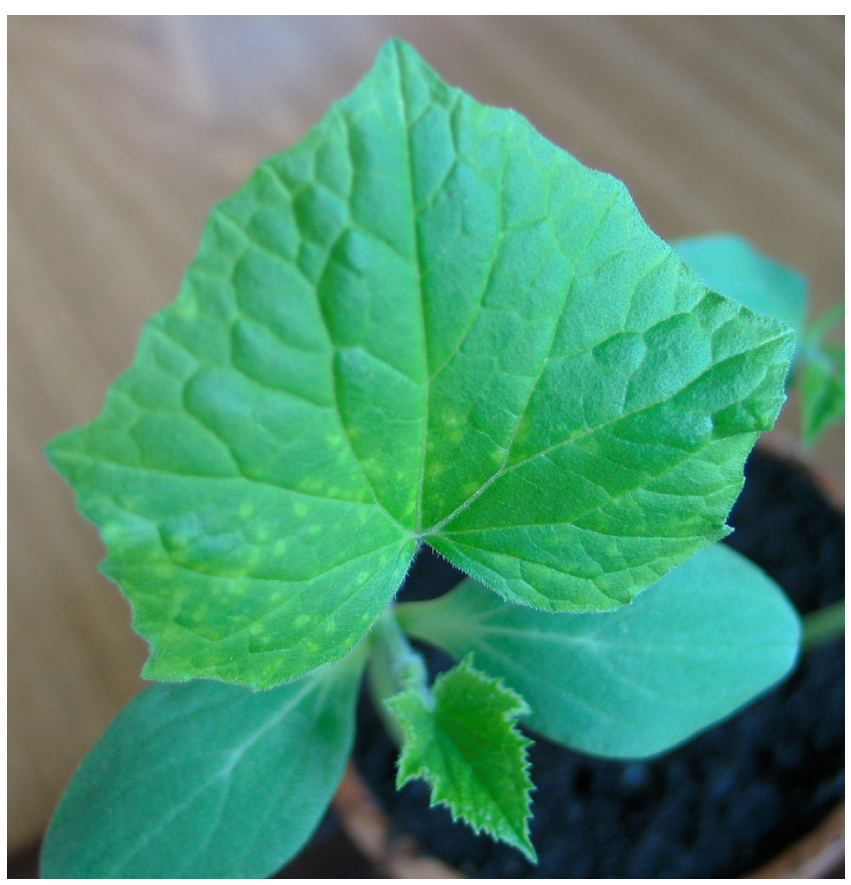

Fig. 2. Systemic symptoms on the Cucumis sativus leaf

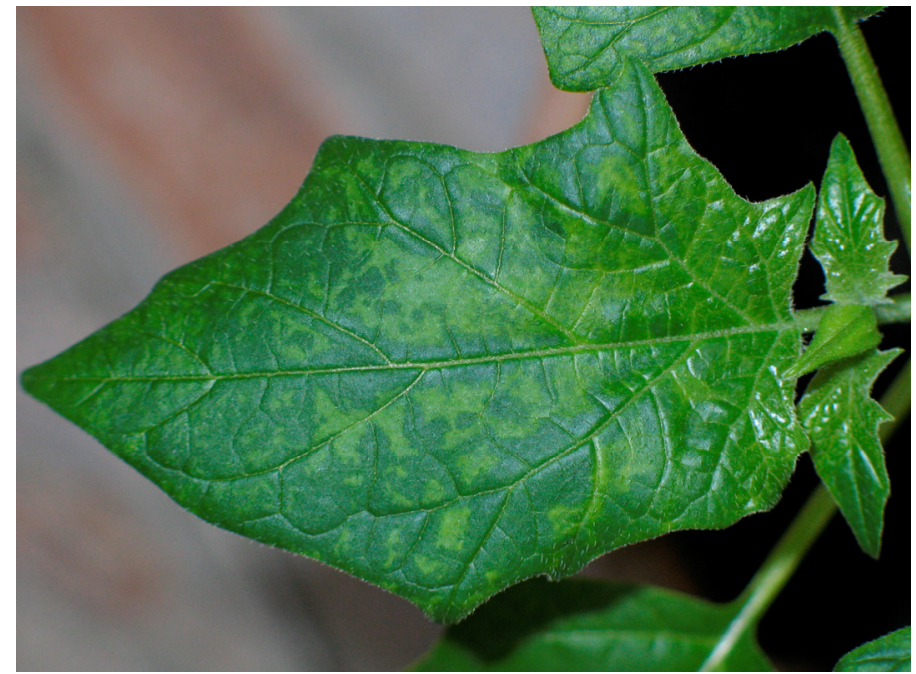

Fig. 3. Systemic symptoms on the leaf of Datura stramonium plant 


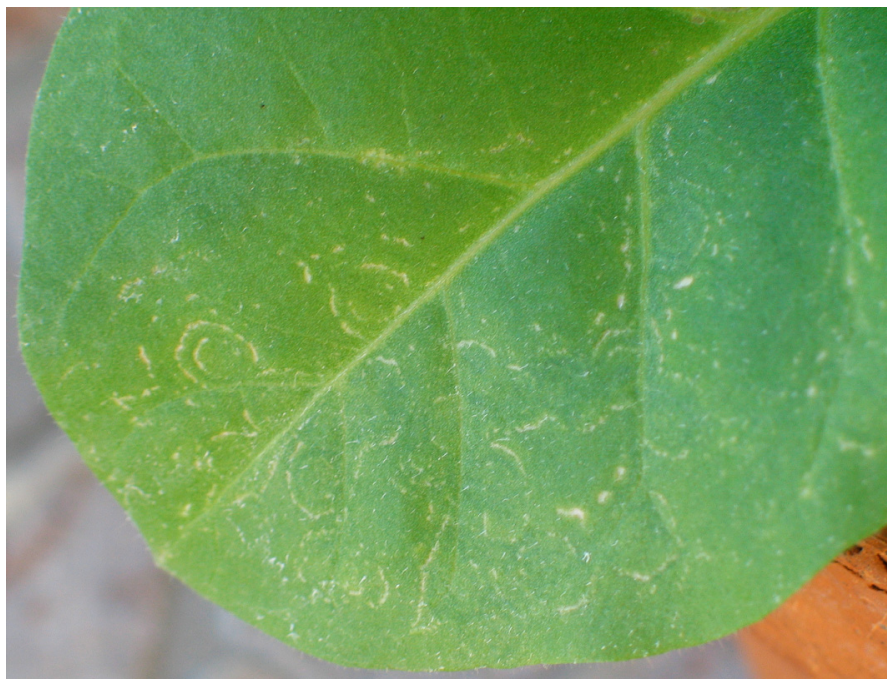

Fig. 4. Local symptoms on the infected leaves of Nicotiana tabacum 'Xanthi'

- Lycopersicon esculentum Mill. 'Potentat' - after 8 days developing mosaic and growth stunting.

- Spinacia oleracea L. - after 3 days chlorotic spots and subsequently chlorosis, mottling and malformation of leaves.

- Vigna unguiculata L. 'Black Eye' - after 5-7 days local necrotic brown spots.

The stability of the virus in the sap from Nicotiana tabacum 'Xanthi' was determined using Chenopodium quinoa plants:

thermal inactivation point (TIP) $55-60^{\circ} \mathrm{C}$,

longevity in vitro $1-2$ days,

dilution end point (DEP) $\log _{10}$ minus $3-4$.

The absorbance readings in DAS-ELISA test were as follows:

tested material $\quad 0.234-0.161$

positive control $0.209-0.230$

negative control $0.002-0.005$

Multiple sequences alignment performed using Mega 4 revealed 99\% nucleotide and amino acid similarity between the investigated isolate and the isolate of CMV from the Netherlands signed RT67 belonging to subgroup II (Deyong et al. 2005). 


\section{DISCUSSION}

The symptoms of yellow mottling and leaf distortion observed on L. angustifolia plants were similar to the symptoms described by Giunchedi and de Ferrer (1972) for the cross-breed Lavandula latifolia $\times$ L. angustifolia infected with the Alfalfa mosaic virus (AMV). The analysis of test plants reactions to inoculation with the isolated virus allowed to identify the pathogen provisionally as CMV and to exclude at the same time the presence of AMV due to absence of systemic reaction in Chenopodium quinoa (van Vlotten-Doting 1981). A positive result of serological test confirmed this preliminary diagnosis.

The obtained isolate, with its very short longevity in vitro (1-2 days) differed significantly from CMV isolates derived from Doronicum caucasicum M.Bieb. (Kobyłko 2000), Aubrieta $\times$ cultorum (Kobyłko and Dańda 2000), Gladiolus hybr. hort. (Kamińska 1976), Forsythia sp. (Kamińska 1983).

Another biological characteristic distinguishing the investigated virus from the above-mentioned isolates was the lack of a local reaction on cotyledons of the inoculated cucumber seedlings.

The examination by RT-PCR method revealed that in spite of the described biological differences, the isolated virus showed strong similarity to the Dutch isolate of CMV signed RT67 belonging to subgroup II (Deyong et al. 2005).

In the light of the foregoing facts the isolated pathogen can be identified as the Cucumber mosaic virus and Lavandula angustifolia may be regarded as its natural host. The fact that English Lavender is a perennial plant makes that species a potentially dangerous host of CMV, because the diseased individuals could constitute original sources of infection for many years.

\section{REFERENCES}

BorodynKo N., JoŃCZYK M., POSPIESZNY H., 2004. Differentiation of Cucumber mosaic virus and Peanut stunt virus by RT-PCR. Progress in Plant Protection 44(2): 604-607.

Deyong Z., Willingmann P., Heinze C., Adam G., Pfunder M., Frey B., FREY J.E., 2005. Differentiation of Cucumber mosaic virus isolates by hybridization to oligonucleotides in a microarray format. J. Virol. Methods 123(1): 101-108.

GIUNCHEDI L., DE FERRER M.M., 1972. Un ceppo di virus del mosaico dell'erba medica isolato da Lavandula latifolia $\times$ L. officinalis. Phytopath. Mediterr. 11: 74-76.

KAMIŃSKA M., 1976. Wirus mozaiki ogórka na mieczyku (Gladiolus hybr. hort.). Zesz. Probl. Post. Nauk Roln. 182: 157-164. 
KAMIŃSKA M., 1983. Choroby wirusowe forsycji (Forsythia sp.).Występowanie, oznaczanie, szkodliwość. Prace Inst. Sadown. i Kwiac. D/14: 1-37.

KoBYŁKo T., 2000. Występowanie wirusów mozaiki ogórka i liściozwoju czereśni na omiegu kaukaskim (Doronicum cancasicum M.Bieb.). Acta Agr. et Silv. 38: $35-44$.

KOBYŁKO T., DAŃDA P., 2000. Identyfikacja czynnika sprawczego rozbicia barwy kwiatów u żagwinu ogrodowego Aubrieta $\times$ cultorum. Zesz. Nauk. AR Kraków 364: 297-300.

VAn Vlotten-Doting L., 1981. Alfalfa mosaic alfamovirus. In: A.A. Brunt, K. Crabtree, M.J. Dallwitz, A.J. Gibbs and L. Watson (eds). Viruses of Plants Descriptions and Lists from the VIDE Database: 78-83.

\section{LAWENDA WĄSKOLISTNA (LAVANDULA ANGUSTIFOLIA MILL.) NATURALNYM GOSPODARZEM WIRUSA MOZAIKI OGÓRKA (CMV)}

Streszczenie: Z rośliny lawendy wąskolistnej wykazującej plamistość i deformację liści wyizolowano patogena. Większość roślin wskaźnikowych użytych do identyfikacji tego izolatu reagowała na mechaniczną inokulację objawami charakterystycznymi dla wirusa mozaiki ogórka (CMV). Cechy określające jego stabilność w soku przedstawiały się następująco: trwałość in vitro (LIV) - 1-2 dni, punkt inaktywacji termicznej (TIP) $-55^{\circ}-60^{\circ} \mathrm{C}$, rozcieńczenie graniczne (DEP) $-\log _{10}$ minus $3-4$. W teście serologicznym DAS-ELISA wyizolowany patogen reagował pozytywnie $\mathrm{z}$ surowicą uczuloną na CMV. Badanie metodą RT - PCR wykazało duże podobieństwo molekularne (99\%) między identyfikowanym patogenem a holenderskim izolatem CMV należącym do podgrupy II.

Przedstawione powyżej wyniki dały podstawę do stwierdzenia, że lawenda była porażona przez wirusa mozaiki ogórka, a to z kolei pozwala zaliczyć tę atrakcyjną roślinę do naturalnych gospodarzy CMV. 